\title{
The Relation between Sustainability Performance and Stock Market Returns: An Empirical Analysis of the Dow Jones Sustainability Index Europe
}

\author{
Akim Van Stekelenburg ${ }^{1}$, Georgios Georgakopoulos ${ }^{2}$, Virginia Sotiropoulou ${ }^{3}$, Konstantinos Z. Vasileiou ${ }^{4} \&$ Ilias \\ Vlachos ${ }^{5}$ \\ ${ }^{1}$ Amsterdam Business School, University of Amsterdam, Netherlands \\ ${ }^{2}$ Strathclyde Business School, University of Strathclyde, UK \\ ${ }^{3}$ Department of Economics, University of Patras, Greece \\ ${ }^{4}$ Department of Business Administration, TEI of Western Greece, Greece \\ ${ }^{5}$ Leeds University Business School, UK \\ Correspondence: Georgios Georgakopoulos, Senior Lecturer, Department of Accounting and Finance, Curran \\ Building Level 3, Room 3.59, 100 Cathedral Street, Glasgow G4 0LN, Scotland. Tel: 44-0-141-548-3936. E-mail: \\ georgios.georgakopoulos@strath.ac.uk
}

Received: February 9, 2015

doi:10.5539/ijef.v7n7p74
Accepted: March 5, 2015

Online Published: June 25, 2015

URL: http://dx.doi.org/10.5539/ijef.v7n7p74

\begin{abstract}
This paper investigates the relation between corporate financial performance (CFP) and corporate sustainability performance (CSP). This is done by first analyzing a sample of European stocks that were added to or deleted from the Dow Jones Sustainability Europe Index (DJSI Europe) over the period 2009-2013, and second by analyzing a sample of European stocks that were recognized as industry group leaders in CSP by the DJSI Europe over the same period. The impacts are measured in terms of (abnormal) stock returns. For the first analysis no strong evidence could be found that the announcement of the inclusion and exclusion events has any significant impact on stock return. However, on the day of change (CD) and in the period following CD, index inclusion (exclusion) stocks experience a significant but temporary increase (decrease) in stock return. These results seem to support Harris and Eitan's (1986) price pressure hypothesis, which postulates that event announcement does not carry information and any shift in demand and hence the corresponding price change is temporary. From the second analysis, on industry group leaders, it can be concluded that the market rewards firms with high CSP. In the period after the day of change, industry group leader stocks experience a permanent and significant positive growth in stock returns. This conclusion can be supported by the resource based perspective, which posits that firms capable of investing heavily in CSP have greater underlying resources which in turn should produce higher financial performance (Alexander \& Bucholz, 1978; Waddock \& Graves, 1997; Clarkson et al., 2006).
\end{abstract}

Keywords: corporate sustainability performance, corporate social responsibility, dow jones sustainability europe index, event study, price pressure hypothesis, resource based perspective

\section{Introduction}

There is a growing interest on sustainability reporting in recent years and while it is not mandatory, most entities choose to report on their social and environmental performance (Solomon \& Solomon, 2006). KPMG publishes its International Survey on Corporate Responsibility Reporting since 1993, and according to the 2011 report approximately $95 \%$ of the 250 largest companies worldwide issue sustainability reports, while this rate was $80 \%$ in 2008 and 50\% in 2005 (KPMG 2005, 2008, 2011). Society, in general, and stakeholders exert increasing pressure to companies to report their corporate sustainability performance (CSP), as apart from their financial performance, the impact of their operations on society and the environment is also considered to be very important (Solomon et al., 2011).

Most research on the relation between CSP and financial performance outcomes has focused on the linkage between corporate social responsibility (CSR) and corporate financial performance (CFP), providing mixed 
results. Some studies found a positive relationship (Waddock \& Graves, 1997; Orlitzky et al., 2003; Margolis \& Walsh, 2001; Cormier \& Magnan, 2007), some a neutral (Bauer et al., 2005; Becchetti et al., 2008; McWilliams et al., 2000) and one a negative (Garcia-Castro et al., 2010).

Although, the literature regarding the relation between CSP and CFP is quite large, the academic research on the relation between CSP or CSR and market returns is rather limited. Freedman and Patten (2004) examined the market reaction to Toxic Releases Inventory and 10-K report environmental disclosures in the US and found that companies with poorer pollution performance suffered from more negative market reactions than companies with better performance. A study conducted in the UK by Lorraine et al. (2004) investigated the relationship between market reactions and publicity regarding fines for environmental pollution and recommendations for good environmental achievements, and it was found a lagged market reaction to the news, especially to the negative news.

Brammer et al. (2006) examined the relation between CSP and stock returns in the UK. They evaluated the interactions between social and financial performance, employing a set of disaggregated social performance indicators for environment, employment, and community activities instead of an aggregate measure, and, surprisingly, they found that that firms with higher social performance scores tend to achieve lower returns, while firms with the lowest possible CSP scores of zero outperformed the market. The authors recognized that the only one available set of social performance indicators to be a limitation, and they concluded that the various aspects of corporate social behaviour must be examined separately in order to achieve an accurate picture of their impact on returns. Finally, Jones et al. (2007) tried to identify, in the Australian context, whether the level of sustainable reporting is associated with market (abnormal stock) returns, but they were unable to draw a definitive conclusion as most of the results were statistically insignificant, although most of the data indicated a negative relation between the two factors.

Thus, the existing research on the relation between CSP and market returns provides mixed results, which can be attributed to various reasons, such as limited amount of indicators, lack of well-developed theoretical foundation, and lack of empirical evidence in the field (Jones et al., 2007). Furthermore, almost all the studies used different measures for CSP and with the most notable exceptions of Cheung (2011), Chih et al. (2010) and Lourenço et al. (2012), most have ignored the leading index for sustainability performance, the Dow Jones Sustainability Index (DJSI). Additionally, almost all researches examined the US or the UK market, and almost none the European.

This research aims to fill this gap by investigating whether European firms with a high CSP experience higher abnormal returns, when this is captured by the DJSI. Thus, this study aims to contribute to the existing literature by using a consistent and widely recognized measure of CSP, the DJSI Europe, in the European market.

In this light, our paper proceeds as follows: In the next section we briefly discuss the terms and concepts of CSP, the measures of CSP, the theoretical framework employed by prior studies and the empirical results. Next, the methodology adopted is described and the research results are presented. The paper ends with the conclusions and recommendations emanating from this research.

\section{Literature Review}

\subsection{Corporate Sustainable Performance}

Wood (2010) considers the CSP domain to be controversial, fluid, ambiguous and difficult to research, although CSP and its sister concepts-corporate social responsibility (CSR), corporate social responsiveness, and corporate citizenship, are present in the management scholarship for about 45 years. To make matters even more complex, according to McWilliam et al. (2006) CSP is often used as a synonym for corporate sustainable responsibility (CSR), although Wood (1991) claims that CSP can be seen as the application of CSR principles. Carroll and Shabana (2010) have a similar view, stating that CSP has become an established umbrella term which embraces both the descriptive and normative aspects of CSR.

Even though there is a large degree of overlap between the concepts of CSR and CSP, they will be considered as two separate notions in this paper. Wood (1991, p. 693) defines CSP as: 'a business organization's configuration of principles of social responsibility, processes of social responsiveness, and policies, programs, and observable outcomes as they relate to the firm's societal relations'. According to Orlitzky et al. (2003) the definition provided by Wood (1991) 'is one of the most influential, helpful, parsimonious, and yet comprehensive conceptualizations of CSP', and therefore it is adopted for the purposes of this study.

\subsection{Theoretical Framework}

So far, there is not an overarching theory explaining the relationship between CSP reporting and financial (accounting or market based) performance (Wood, 2010), although the first inquiry for such a theory dates back 
to 1985 when Ulman concluded that 'the situation pertaining to the relationships among social performance, social disclosure, and economic performance can best be characterized at this time as empirical data in search of an adequate theory.' Thus, several theories have been developed to explain the linkage between sustainable performance and firm performance (McWilliams \& Siegel, 2001).

The most commonly used theory is the stakeholder theory. Freeman (1984) defined stakeholder as any group or individual who can affect or is affected by the achievement of the organization's objectives. This theory tries to identify which groups within and outside of an organization are stakeholders, and should be taken into consideration by management. There are two types of stakeholders; primary stakeholders are 'One without whose continuing participation the company cannot survive' and secondary stakeholders are 'those who influence or affect, or are influenced or affected by, the corporation, but they are not engaged in transactions with the corporation and are not essential for its survival' (Clarkson, 1995, pp. 106-107).

The framework developed by Ullmann (1985), based on the stakeholder approach to strategic management, proposes that stakeholders ultimately control a firm's access to scarce resources and firms must manage their relation with key stakeholders to ensure that such access is maintained (Roberts, 1992). Since then stakeholder theory has been widely used for empirical analyses relating to CPS (Ruf et al., 2001; Chih et al., 2010; Jones et al., 2009; Ziegler, 2012).

Another theory that aims to explain the relation between CSP and market performance is the resource-based perspective (RBP). Since firms may view meeting stakeholder demands as a strategic investment, they try to satisfy stakeholders beyond the minimum necessary commitments (Ruf et al., 2001; Laurenço et al., 2012). Under the RPB it is suggested that organizations can generate sustainable competitive advantages by effectively controlling and manipulating their resources that are, rare, cannot be perfectly imitated, and for which no perfect substitute is available (Laurenço et al., 2012). Furthermore, external benefits of CSP are related to corporate reputation, which has been identified as one of the most important intangible resources that provide a firm sustainable competitive advantage, as companies with high CSP reputation are able to improve relations with external stakeholders such as customers, investors, bankers, suppliers, and competitors (Roberts \& Dowling, 2002; Orlitzky et al., 2003; Laurenço et al., 2012).

In conclusion, sustainable performance, in the long run, can raise benefits through improved relations with stakeholders and reduced cost of conflicts with them and increase reputation creation, which makes an organization more attractive to investors (Laurenço et al., 2012).

\subsection{Measures of Corporate Sustainable Performance}

According to Waddock and Graves (1997) CSP is a multidimensional construct, which is not only hard to define but also hard to measure. Despite this difficulty, because of the increasing interest for CSP and CSR activities, the need for their measurement has also increased.

Ulmann (1985) was one of the first who tried to identify and summarize different types of CSP measurements. Based on an assessment of 31 empirical studies conducted in the 70's and early 80's, he categorized three broad measures for CSP; social disclosures (such as voluntary corporate social reporting and mandatory disclosures on pollution), social performance (such reputational indexes or rankings) and economic performance (such as shareholder returns, price/earnings ratio, return on equity, net income, or net profit margin). Orlitzky et al. (2003) also identified four categories of CSP measures: 1) CSP disclosures, 2) CSP reputation ratings, 3) social audits, processes and observable outcomes, and 4) managerial CSP principles and values.

Wood (2010) conducted an extensive literature review on CSP and its measures. He concluded that one the most frequently used CSP measures is the KLD rating. The KDL rating emerged from the mutual fund offered by the Kinder, Lydenberg, and Domini, Company Inc. in 1988, which included US companies of Standard \& Poor 500 that lack of participation in such 'irresponsible' fields as military contracting, South Africa, tobacco products, gambling and nuclear power. Over time, KLD added positive screens to their ratings and their SOCRATES database is now widely used as a way of calculating CSP in empirical studies (Wood, 2010). KLD and similar ratings are sometimes used as aggregate measures of overall CSP.

Given the large variety of measures have been proposed to evaluate CSP, the lack of consensus as to which of them are the most appropriate is not surprising. However, there is a growing popularity of indices, such as the Dow Jones Sustainability Index, FTSE4Good and the Domini 400, which have been initiated in the past few years. Moreover, the inclusion (exclusion) of a firm in reputation indices has been recognized as a sound measure for high (low) sustainable performance (Ulmann, 1985; Orlitzky et al., 2003).

Similar to prior literature, current analysis infers a company’s level of CSP as high (low) by inclusion (exclusion) 
in a reputation index, in this case Dow Jones Sustainability Europe Index (DJSI Europe).

The DJSI Europe was established in August 2010 to evaluate the sustainable performance of the region's largest companies. These companies are assessed by RobecoSAM using the annual Corporate Sustainability Assessment (CSA). Established in 1999, as the first ever family of global sustainability benchmarks, the Dow Jones Sustainability Indices (DJSI) have become a reference point in Sustainability Investing (DJSI Europe Index Guide, 2013).

The DJSI family uses what they refer to as a best-in-class approach to select sustainability leaders from across all industries based on pre-defined sustainability criteria embedded in the CSA, namely: 1) no industry is excluded from the indices, with the most sustainable companies in each industry selected for index membership, 2) companies receive a Total Sustainability Score between 0-100 and are ranked against other companies in their industry, and 3) only the top $20 \%$ of companies from each industry, based on their sustainability score, are included in the Dow Jones Sustainability Europe Index (DJSI Europe Index Guide, 2013).

As a result companies must continually intensify their sustainability initiatives to be included or remain in the index. Furthermore, a growing number of companies define the inclusion in the DJSI as a corporate goal, as it publicly endorses their approach to addressing key sustainability issues. The Corporate Sustainability Assessment used by the DJSI consists out of several components, such as identifying which companies are better equipped to recognize and respond to emerging sustainability opportunities and challenges presented by global and industry trends, as well as a Media and Stakeholder Analysis (MSA). Moreover, companies that generate any revenue from producing or participation in the production of alcohol, tobacco, gambling, armaments (if $>5 \%$ of total revenues), cluster bombs, landmines, firearms, nuclear, and adult entertainment, will be excluded from the subset indices. Finally, The DJSI Europe is reviewed annually and rebalanced quarterly to ensure that the index composition accurately represents the top $20 \%$ of the leading sustainable European companies. The resulting changes to the index composition are announced on the annual review date in September (DJSI Europe Index Guide, 2013).

\subsection{Empirical Results on the Relationship between CSP and Firm Financial Performance}

The empirical evidence on the relationship between CSP and firm value primarily takes an investment perspective and focuses mainly on whether sustainable performance is 'priced' in capital markets (e.g. Lo \& Shue, 2007) or whether highly sustainable companies outperform other companies in terms of financial performance (e.g. Konar \& Cohen, 2001; Lopez et al., 2007; Becchetti et al., 2008; Chih et al., 2010; Lourenço et al., 2012). These studies have produced interesting, albeit contradicting results.

Konar and Cohen (2001) investigated the relation between the market value of firms in the S\&P 500 and objective measures of their environmental performance and they concluded that bad environmental performance is negatively correlated with the intangible asset value of firms. However, Lopez et al. (2007) found that there is a negative correlation between financial and sustainable performance, or at least during the first years in which sustainability practices are applied. Similar findings derived from Chih et al. (2010) attempt to specify the conditions under which corporations may or may not act in socially responsible ways, where it was found, amongst others, that firms with larger size are more CSR minded, and that the financial performance and CSR are not related.

Other studies use the standard event approach, whose main advantage compared to the above mentioned approaches is that by looking into how stock markets respond to these events, it is possible to realize whether CSP matters to investors or not. Furthermore, by varying the length of the event window, it provides an understanding to both short- and long-term stock behaviours. Bauer et al. (2004) used an international database containing 103 German, UK and US ethical mutual funds, and they found that when examining the investment style, there was no evidence of significant differences in risk-adjusted returns between ethical and conventional funds for the period 1990-2001. Contrariwise, Consolandi et al. (2009), when conducting an event study on the Dow Jones Sustainability Stoxx Index (DJSI Stoxx), concluded that the evaluation of the CSP performance of a firm is a significant criterion for asset allocation activities over the period 2001-2006. However, Cheung (2011), found that announcement has not any significant impact on stock return, when he analysed the impact of Dow Jones World Index (DJSI World) firm inclusions and exclusions for a sample of US stocks over the period 2002-2008. Finally, Orbendorfer et al. (2013) examined the effect of the inclusion of German corporations in the DJSI World and the DJSI Stoxx on stock performance, and they concluded that stock markets may penalize the inclusion of a firm in a sustainability index, which is due to a strong negative impact of firm inclusion in the DJSI World. 


\section{Research Hypotheses}

Several theories have emerged in order to explain the strong empirical evidence of positive (negative) impact of firm sustainability index inclusion (exclusion) events. Some of these are the downward sloping demand curve hypothesis (Shleifer, 1986), the price pressure hypothesis (Harris \& Eitan, 1986), the information cost hypothesis (Merton, 1987) and the signalling hypothesis (Jain, 1987; Dhillon \& Johnson, 1991; Denis et al., 2003). The first two hypotheses assume that index inclusion and exclusion events do not contain information, and thus they do not affect security prices, attributing the changes in demand mainly to the non-information-based portfolio allocation. According to the downward sloping demand curve hypothesis the increase in demand is believed to be permanent, whereas, the price pressure hypothesis supports that the increase in demand is of a temporary nature and that the price and volume impacts are also temporary.

In contrast, the other two hypotheses do assume that an event carries information, and subsequently it has an effect on the fundamental value of a security. Particularly, the information cost hypothesis argues that index events lead to an increase in investor awareness and decreases information searching costs, as the index makes more information available to investors. As suggested by the name, the signalling hypothesis supports that index events are interpreted by investors as signals that convey information regarding the future of a security, due to private information possessed by the index institution that results in these events. Thus, other things being equal, an expected increase (decrease) in the future value of the security leads to an increase (decrease) in share price.

This research adopts the last two hypotheses and hence the first hypothesis is:

Hypothesis 1a: Firms added to the DJSI Europe, experience a positive market reaction to the news of their inclusion.

And subsequently:

Hypothesis 1b: Firms removed from the DJSI Europe, experience a negative market reaction to the news of their exclusion.

Next to determining the top 20\% sustainable performers out of the largest 600 European companies, the DJSI also tracks CSP per industry group. The index has a total of 24 industry groups ranging from the automotive industry to food and beverage producers. For each industry, per year, an industry leader is appointed. These 24 firms have been recognized to achieve the highest sustainable performance, comparing to the rest of their respective peer groups. The industry group leaders are based on the DJSI Worldwide, therefore the number of European firms that are industry group leader varies.

As suggested by the resource-based perspective of CSP theory, organizations that can generate sustainable competitive advantages by effectively controlling and manipulating their rare resources, cannot be perfectly imitated (Laurenço et al., 2012). Furthermore, external benefits of CSP are related to corporate reputation, which has been identified as one of the most important intangible resources that provide a firm sustainable competitive advantage (Roberts \& Dowling, 2002; Orlitzky et al., 2003; Laurenço et al., 2012).

Hence, the second research hypothesis is:

Hypothesis 2: European firms recognized as industry group leader by the Dow Jones Sustainability Index Europe, experience a positive market reaction to the news of their achievement.

\section{Methodology and Data Collection}

\subsection{Methodology}

This research employed a quantitative research method using standard event study methodology. Unlike most other researches conducted with an event study methodology, a two pronged approach was adopted. At the first stage, standard event study methodology is used to determine whether the Cumulative Average Abnormal Returns (CAAR) for firms included (excluded) in the DJSI Europe exhibit a statistically significant increase (decrease) during the event period, which is consistent with prior literature (e.g. Bauer et al., 2005; Ziegler \& Schröder, 2007; Curran \& Moran, 2007; Cheung, 2011). At the second stage, this study moves a step forward by conducting a separate event study for firms that have been recognized as industry group leader.

The study sample period is from 2009 to 2013. The following data have been provided by the DJSI Europe and RobecoSAM:

(i) The announcement day of index inclusion and index exclusion events;

(ii) The effective day of index exclusion and index inclusion events;

(iii) The names of the above companies; and 
(iv) Industry group leader firms.

Standard event study methodology is used to compare these variables before and after index inclusion (or index exclusion) events. Two sets of event days are used: the announcement days (AD) and the days of change (CD). The length between AD and CD is generally 5 trading days for the years 2010, 2011, 2012 and 2013, with the exception of 10 trading days in 2009 .

Following Cheung (2011) the sample is first divided into two periods. The first period is called the estimation period that contains observations from $\mathrm{t}=-250$ to $\mathrm{t}=-16$ in order to calculate $\beta i$ (see model 4), while the second period is labelled the event period that starts from $t=0$ to $t=60$ where a relevant window is examined. For each security, the complete event window runs from 15 days before AD through to 60 days after $\mathrm{CD}$. Based upon research conducted by Lynch and Mendenhall (1997) and Chueng (2011), the complete window is further divided into seven sub-windows, which are designed to assess different aspects of stock behaviour around the events. In addition to the standard $\mathrm{AD}$ and $\mathrm{CD}$ windows, these sub-windows include:

(1) Pre-announcement window that lies between AD-15 and AD-1.

(2) Run-up window that spans from the day after $A D$ through to the day before $C D$.

(3) Three release-related windows that run from $\mathrm{CD}$ to $\mathrm{CD}+10$; they include release windows during $\mathrm{CD}$ and $\mathrm{CD}+4$ and a post release windows $(\mathrm{CD}+5, \mathrm{CD}+10)$, respectively.

(4) Temporary price impact windows that cover periods within AD-15 and CD+10.

(5) Total permanent price impact windows that fall within $\mathrm{AD}-15$ and $\mathrm{CD}+60$.

The pre-announcement window aims to detect the existence of an anticipation effect before the announcement, while the run-up window is used to test for possible price changes between $\mathrm{AD}$ and $\mathrm{CD}$. The three release-related windows allow for an examination of the short-term impact of $\mathrm{CD}$ on stock prices. The final two sets of windows distinguish between temporary price changes and permanent ones.

The proxy used for stock price movements is abnormal stock returns. The necessary data were collected from Compustat Global - Security Daily and the CRSP Stock Daily.

Abnormal return of stock $i$ at time $t$ is defined as the difference between realized return and an estimate of its expected (or normal) return in the absence of the event.

$$
A R_{i t}=R_{i t}-E\left(R_{i t}\right)
$$

Cumulative abnormal returns (CAR) during the event period $\left(\mathrm{t}_{1}, \mathrm{t}_{2}\right)$ are given by:

$$
C A R_{\left(t_{1}, t_{2}\right)}=\sum_{t=t_{1}}^{t_{2}} A R_{i, t}
$$

The Cumulative average abnormal returns (CAAR) are calculated by:

$$
\operatorname{CAAR}_{\left(t_{1}, t_{2}\right)}=\frac{1}{N} \sum_{i=1}^{N} C A R_{\left(t_{1}, t_{2}\right)}
$$

Abnormal returns (cumulative abnormal returns) capture the excess returns an investor would have received over a particular event day (event period) if one had invested in security $i$. It is assumed that abnormal returns $\left(A R_{i t}\right)$ are (normally) distributed with mean zero and variance $\sigma_{i}^{2}$.

Following MacKinlay (1997), the market model is used to compute $E\left(R_{i t}\right)$. The market model is a statistical model which relates the return of any given security to the return of the market portfolio. The model's linear specification follows from the assumed joint normality of asset returns. For any security $i$ the market model is:

$$
E\left(R_{i t}\right)=\alpha_{i}+\beta_{i} R_{m t}+\varepsilon_{i t}
$$

Where:

- $R_{m t}$ is the market portfolio;

- $\varepsilon_{i t}$ is the zero mean disturbance term;

- $\alpha_{i}, \beta_{i}$ are the parameters of the market model determined through an OLS regression.

Generally, a broad based stock index is used for the market portfolio, with the S\&P 500 Index, the CRSP Value Weighted Index, and the CRSP Equal Weighted Index being popular choices (MacKinlay, 1997). This study uses the STOXX Europe 600 as the benchmark market. The market model is one of the most popular methods for 
computing expected returns in an event study setting. Furthermore, it represents a potential improvement over the other popular methods, such as the constant mean return model. By removing the portion of the return that is related to variation in the market's return, the variance of the abnormal return is reduced. This in turn can lead to increased ability to detect event effects (MacKinlay, 1997). Finally, examining the various models used in an event study context, Ahern (2009) found that the use of multifactor models such as the Fama and French 3 factor model and the Carhart 4 factor model does not decrease the forecast error bias that might be present in simpler methods. Therefore, consistent with prior literature (e.g. Freedman \& Patten, 2004; Curran \& Moran, 2007; Consolandi et al., 2009) the market model was chosen.

In order to test for the significance of cumulative average abnormal returns over the event period, a parametric test, the cross-sectional $t$ statistic and a non-parametric test, Corrado and Zivney's (1992) sign statistic are used, as recommended by Ahern (2009).

\subsection{Sample of the Study}

\subsubsection{Sample for Hypotheses H1a and H1b}

Panel A of Table 1 displays the frequency of index inclusions and exclusions per year. There are 119 index inclusions and 98 index exclusions events. The total number of events per year varies from its lowest (37) in 2011 to its highest (47) in 2013. The sample consists of 166 firms that were added to or deleted from the DJSI Europe during the period of 2009-2013. The total number of firms (i.e. 166) is less than the total number of events (i.e. 215) because many firms such as AEGON N.V., ArcelorMittal, ING N.V., and Volkswagen were added and deleted in different years of the sampling period. These 166 firms come from various countries and different industry sectors (Panel B and Panel C, respectively). United Kingdom is the country with the highest participation (around 25\% of the total sample), followed by France, Germany and the Netherlands in the next three places, respectively. A wide variety of industries is included in the sample, however, the industrial goods and services is the sector with most firms.

Table 1. Sample of the study by year, country and industry

\begin{tabular}{|c|c|c|c|c|c|c|c|}
\hline \multicolumn{4}{|c|}{$\begin{array}{l}\text { Panel A: Number of firms included in and } \\
\text { excluded by DJSI Europe by year }\end{array}$} & \multicolumn{2}{|c|}{$\begin{array}{l}\text { Panel B: Sample of the } \\
\text { study by country }\end{array}$} & \multicolumn{2}{|c|}{ Panel C: Sample of the study by industry } \\
\hline Year & $\begin{array}{l}\text { No. of index } \\
\text { inclusions }\end{array}$ & $\begin{array}{l}\text { No. of index } \\
\text { exclusions }\end{array}$ & Total & Country & $\begin{array}{c}\text { Numb } \\
\text { er }\end{array}$ & Industry & Number \\
\hline 2009 & 19 & 25 & 44 & Belgium & 2 & Automobiles \& Parts & 4 \\
\hline 2010 & 29 & 16 & 45 & Denmark & 2 & Banks & 14 \\
\hline 2011 & 23 & 14 & 37 & Finland & 8 & Basic Resources & 8 \\
\hline 2012 & 18 & 24 & 42 & France & 36 & Chemicals & 8 \\
\hline 2013 & 29 & 18 & 47 & Germany & 16 & Construction \& Materials & 8 \\
\hline \multirow[t]{15}{*}{ Total } & 119 & 98 & 215 & Italy & 9 & Financial Services & 5 \\
\hline & & & & Netherlands & 14 & Food \& Beverage & 5 \\
\hline & & & & Norway & 7 & Health Care & 5 \\
\hline & & & & Portugal & 2 & Industrial Goods \& Services & 33 \\
\hline & & & & Spain & 14 & Insurance & 8 \\
\hline & & & & Sweden & 6 & Media & 8 \\
\hline & & & & Switzerland & 10 & Oil \& Gas & 9 \\
\hline & & & & United Kingdom & 40 & Personal \& Household Goods & 9 \\
\hline & & & & Total & 166 & Real estate & 5 \\
\hline & & & & & & Retail & 10 \\
\hline & & & & & & Technology & 7 \\
\hline & & & & & & Telecommunications & 5 \\
\hline & & & & & & Travel \& Leisure & 6 \\
\hline & & & & & & Utilities & 9 \\
\hline & & & & & & Total & 166 \\
\hline
\end{tabular}

\subsubsection{Sample for Hypotheses H2}

Panel A of Table 2 displays the total number of European industry group leaders per year. 65 European firms had been appointed as group leader by the DJSI over the period 2009 to 2013 . The sample consists of 34 firms, while 
the total number of events is 65, because some firms such as Air France-KLM, BMW AG, Roche Holding AG and Swiss Reinsurance Co. were group leaders for several subsequent years during the sampling period. Panel B and Panel $\mathrm{C}$ refer to the sample composition in terms of country origin and industry involved.

Table 2. European industry group leaders in the sample by year, country and industry

\begin{tabular}{|c|c|c|c|c|c|c|c|}
\hline \multicolumn{2}{|c|}{ Panel A: By year } & \multicolumn{3}{|c|}{ Panel B: By country } & \multicolumn{3}{|c|}{ Panel C: By industry } \\
\hline Year & Number & Country & Number & Percent & Industry & Number & Percent \\
\hline 2009 & 14 & Belgium & 1 & 2.94 & Automobiles \& Parts & 2 & 5.88 \\
\hline 2010 & 12 & Finland & 2 & 5.88 & Basic Resources & 2 & 5.88 \\
\hline 2011 & 11 & France & 4 & 11.76 & Chemicals & 2 & 5.88 \\
\hline 2012 & 14 & Germany & 7 & 20.59 & Food \& Beverage & 3 & 8.82 \\
\hline 2013 & 14 & Netherlands & 6 & 17.65 & Health Care & 1 & 2.94 \\
\hline \multirow[t]{11}{*}{ Total } & 65 & Portugal & 1 & 2.94 & Industrial Goods \& Services & 4 & 11.76 \\
\hline & & Spain & 4 & 11.76 & Insurance & 2 & 5.88 \\
\hline & & Switzerland & 4 & 11.76 & Media & 2 & 5.88 \\
\hline & & United Kingdom & 5 & 14.71 & Oil \& Gas & 3 & 8.82 \\
\hline & & Total & 34 & 100.00 & Personal \& Household Goods & 3 & 8.82 \\
\hline & & & & & Retail & 1 & 2.94 \\
\hline & & & & & Technology & 3 & 8.82 \\
\hline & & & & & Telecommunications & 1 & 2.94 \\
\hline & & & & & Travel \& Leisure & 2 & 5.88 \\
\hline & & & & & Utilities & 3 & 8.82 \\
\hline & & & & & Total & 34 & 100.00 \\
\hline
\end{tabular}

\section{Research Results}

\subsection{Descriptive Statistics}

Panel A of Table 3 shows the average and standard deviation of daily returns, per subsample, per year, whereas Panel B shows additional summary statistics, such as skewness and kurtosis. When looking at the average daily returns on a yearly basis in Panel A, non significant differences are detected between the inclusion and exclusion stocks, with the exception of 2013. However, according to Panel B, it is clear that while the samples are approximately symmetric (i.e. the skewness is within normal boundaries), the kurtosis is rather high, which might suggest non-normal data. This justifies the use of the sign-test statistic for hypothesis testing, as it has proven to be highly suitable for non-normal data (Corrado \& Zivney, 1992).

Table 3. Descriptive statistics of daily returns for the sample of hypotheses H1a and H1b

\begin{tabular}{|c|c|c|c|c|}
\hline \multicolumn{5}{|l|}{ Panel A } \\
\hline \multirow[t]{2}{*}{ Year } & \multicolumn{2}{|c|}{ Average } & \multicolumn{2}{|c|}{ Std. deviation } \\
\hline & Incl. (\%) & Excl. (\%) & Incl. (\%) & Excl. (\%) \\
\hline 2009 & 0.120 & 0.129 & 1.943 & 2.165 \\
\hline 2010 & 0.151 & 0.112 & 1.627 & 1.554 \\
\hline 2011 & 0.083 & 0.085 & 3.657 & 3.540 \\
\hline 2012 & 0.060 & 0.099 & 1.557 & 1.826 \\
\hline 2013 & 0.023 & 0.057 & 1.460 & 1.397 \\
\hline \multicolumn{5}{|l|}{ Panel B } \\
\hline Types & Index Inclusions & Inde & Isions & Whole sample \\
\hline Mean & $4.48 \mathrm{e}-04$ & & & $5.64 \mathrm{e}-04$ \\
\hline SD & $2.16 \mathrm{e}-02$ & & & $2.15 \mathrm{e}-02$ \\
\hline Skewness & 0.122 & & & 0.042 \\
\hline Kurtosis & 8.433 & & & 8.100 \\
\hline
\end{tabular}

According to Table 4 the average daily returns for the sample of hypothesis $\mathrm{H} 2$ are higher than those of hypotheses $\mathrm{Hla}$ and $\mathrm{H} 1 \mathrm{~b}$, indicating that investors react stronger to firms that have been recognized as industry 
group leaders than the others. The sample of $\mathrm{H} 2$ has a high kurtosis, combined with a moderately skewed distribution, which might suggest non-normal data. This justifies the use of the sign-statistic for hypothesis testing, especially combined with the smaller sample for this hypothesis.

Table 4. Descriptive statistics of daily returns for the sample of hypothesis 2

\begin{tabular}{lcc}
\hline Panel A & & \\
\hline Year & Avg. daily returns (\%) & Std. deviation (\%) \\
\hline 2009 & 0.140 & 1.596 \\
2010 & 0.167 & 1.576 \\
2011 & 0.004 & 2.708 \\
2012 & 0.151 & 1.789 \\
2013 & 0.142 & 1.533 \\
\hline Panel B & & \\
Mean & $1.29 \mathrm{E}-03$ & \\
SD & $1.82 \mathrm{E}-02$ & \\
Skewness & 0.563 & \\
Kurtosis & 7.469 & \\
\hline
\end{tabular}

\subsection{Index Inclusion and Exclusion Results (H1a \& H1b)}

In order to ensure that market responses to the events are isolated to the two separate hypotheses, all index constituent stocks are classified into two groups. The firs group contains those stock newly included to the DJSI Europe, while the second contains those stocks newly deleted from the index.

The trading behaviour is examined separately for stocks newly included to and excluded from the DJSI Europe, in order to investigate whether there is abnormal trading behaviour after the announcement day (or the day of change) (hypotheses H1a and H1b, respectively). According to Panel A of Table 5 there is no evidence to support there is an announcement effect for index inclusions, given that the overall result of $(\mathrm{AD}, \mathrm{AD}+4)$ window is not statistically significant and that in other daily windows, no significant results are found. Moreover, there is some weak statistical evidence of an effective change effect, as for the $(\mathrm{CD}, \mathrm{CD})$ window both the sign-test and the t-test for CAAR are significant, suggesting that investors respond negatively on the day new stocks are included to the DSJI Europe. Furthermore, for the $(\mathrm{CD}+3, \mathrm{CD}+3)$ the sign-test was negatively significant. Panel $\mathrm{B}$ of Table 5 reports that the CAAR in the first 5 trading days after the announcement of index exclusion is statistically not distinguishable from zero. However, it is found that the CAAR is significant for $(C D+2, C D+2)$, $(C D+3, C D+3)$ and $(C D+4, C D+4)$, with the first being positively significant and the latter two negatively, which might hint at lagged negative response to the news from the market.

Table 5. CAARs in the first 5 days after AD (or CD) for the samples of H1a and H1b

\begin{tabular}{|c|c|c|c|c|c|c|}
\hline \multirow{2}{*}{$\begin{array}{l}\text { Period 2009-2013 } \\
\text { Event window }\end{array}$} & \multicolumn{3}{|c|}{ Panel A: index inclusions } & \multicolumn{3}{|c|}{ Panel B: index exclusions } \\
\hline & CAAR (\%) & Sign-test statistic & t-test & CAAR (\%) & Sign-test statistic & t-test \\
\hline$(\mathrm{AD}, \mathrm{AD})$ & 0.171 & 1.614 & 1.624 & 0.203 & 1.188 & 0.918 \\
\hline$(\mathrm{AD}+1, \mathrm{AD}+1)$ & 0.005 & 0.861 & 0.046 & 0.086 & 0.517 & 0.959 \\
\hline$(\mathrm{AD}+2, \mathrm{AD}+2)$ & 0.066 & 0.268 & 0.603 & 0.059 & 0.154 & 0.635 \\
\hline$(\mathrm{AD}+3, \mathrm{AD}+3)$ & 0.174 & 0.297 & 0.945 & 0.009 & 0.294 & 0.164 \\
\hline$(\mathrm{AD}, \mathrm{AD}+4)$ & 0.127 & 1.397 & 0.604 & 0.141 & 1.495 & 0.374 \\
\hline$(\mathrm{CD}, \mathrm{CD})$ & 0.257 & $2.179 * *$ & $2.234 * *$ & 0.128 & 0.741 & 1.396 \\
\hline$(\mathrm{CD}+1, \mathrm{CD}+1)$ & 0.011 & 0.832 & 0.100 & 0.244 & 0.741 & 1.300 \\
\hline$(\mathrm{CD}+2, \mathrm{CD}+2)$ & 0.104 & 0.079 & 0.787 & 0.140 & $2.837 * * *$ & 0.766 \\
\hline$(\mathrm{CD}+3, \mathrm{CD}+3)$ & 0.029 & $1.802 *$ & 0.206 & 0.279 & 1.188 & $2.826 * * *$ \\
\hline$(\mathrm{CD}+4, \mathrm{CD}+4)$ & 0.006 & 0.079 & 0.056 & 0.205 & 0.377 & $1.696^{*}$ \\
\hline$(\mathrm{CD}, \mathrm{CD}+4)$ & 0.025 & 0.297 & 0.118 & 0.260 & 1.272 & 0.637 \\
\hline
\end{tabular}

Note. ${ }^{*}, * *$, and $* * *$ denote significance at the 10,5 and $1 \%$ level, respectively.

Figure 1 presents the time-series behaviour of CAARs in the complete window spanning from $\mathrm{AD}-15$ to $\mathrm{CD}+60$, 
providing a clearer picture than the Table 5, which focuses only on the first five trading days. Regarding the index inclusion stocks, there seems to be an anticipation effect given that the CAAR starts increasing from negative values a few days before the announcement. However, there is a loss in momentum when the announcement is made as well as the following day. Moreover, the day of change impact can be clearly seen when looking at the CAARs roughly 6 days after AD. It is also quite clear that stocks included in the index experience an upward price movement, however, this is a highly temporary effect because prices decrease later in the period, which might suggest a price reversal effect.

Figure 1 also shows that CAARs of index exclusions take a dive after the announcement idate. There seems to be a slight movement to recovery roughly 18 days after AD, but relapse further downward. Similar to the index inclusion stocks the day of change impact can clearly be seen. However, while there was some evidence of price reversal later on for index inclusion stocks, this does not apply to the index exclusions, indicating that the market reacts more heavily on stocks that were excluded from the index compared to those included.

Figure 1 does not allow to distinguish the impact of $\mathrm{AD}$ from that of $\mathrm{CD}$, and it does not indicate whether the persistence or price reversal is statistically significant or not. In order to overcome these limitations a detailed analysis on shorter windows is shown in Table 6.

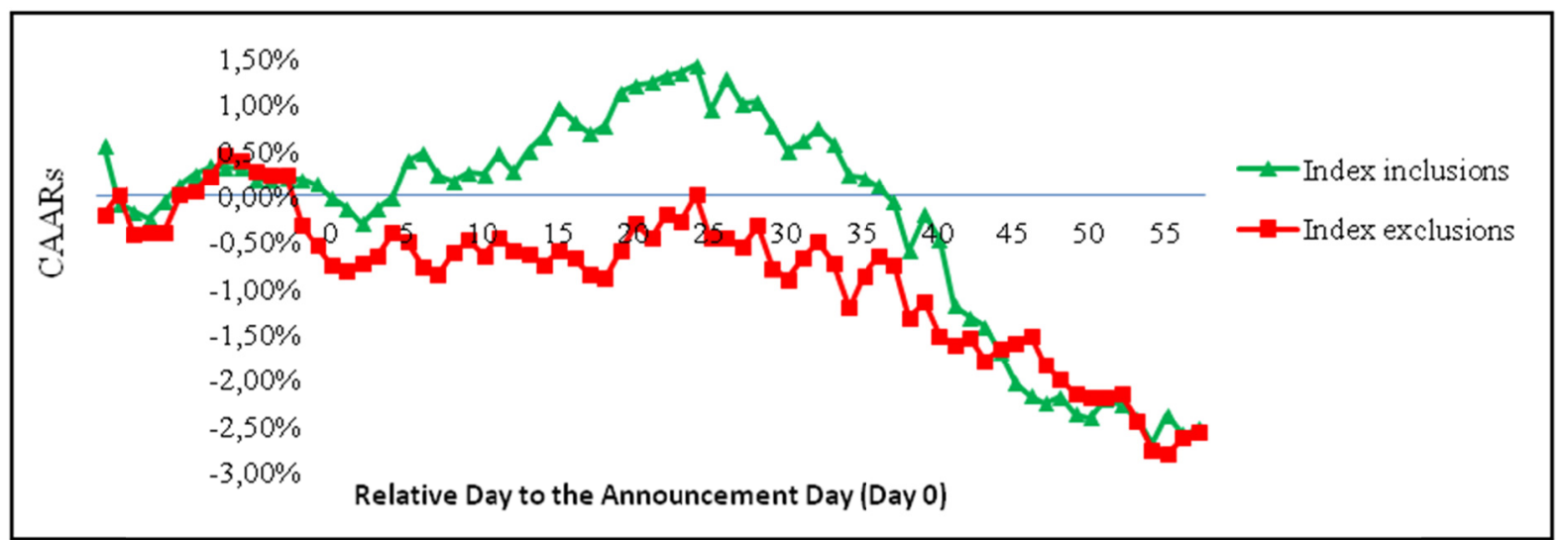

Figure 1. CAARs for the samples of H1a and H1b

Panel A of Table 6 shows that the CAAR on the pre-AD (AD-10, AD-1) window is positive but statistically insignificant suggesting that the market does not anticipate the events. The same can be concluded for the various $\mathrm{AD}$ windows with lengths ranging from 1, 2 to 3 days before or after the announcement day. Moreover, no statistically significant CAAR can be found in the window from the day after the announcement until the day before the effective change. This also applies to the release $(\mathrm{CD}, \mathrm{CD}+4)$ and post-release window $(\mathrm{CD}+5$, $\mathrm{CD}+10)$.

No significant CAARs were found for both the $(A D, C D+10)$ and the $(A D-15, C D+10)$ windows, although the CAARs themselves are highly positive. However, although the statistics for the $(A D, C D+30)$ window indicate that there is a positive permanent price effect, those for the (AD-15, CD+60) window indicate the contrary. Hence, it can be concluded that the price changes found on AD and CD windows are temporary and do not last long for index inclusion stocks.

Table 6. CAARs in smaller event windows for the samples of $\mathrm{H} 1 \mathrm{a}$ and $\mathrm{H} 1 \mathrm{~b}$

\begin{tabular}{lllllll}
\hline Period 2009-2013 & \multicolumn{2}{l}{ Panel A: index inclusions } & \multicolumn{3}{l}{ Panel B: index exclusions } \\
\hline Event window & CAAR (\%) & Sign-test statistic & t-test & CAAR (\%) & Sign-test statistic & t-test \\
\hline (AD-10, AD-1) & 0.046 & 1.397 & 0.126 & 0.583 & 0.517 & $1.831^{*}$ \\
(AD-1, AD+1) & 0.332 & 1.426 & $1.804^{*}$ & 0.531 & 0.965 & $2.934^{* * *}$ \\
(AD-2, AD+2) & 0.178 & 0.109 & 0.802 & 0.184 & 0.741 & 1.037 \\
(AD-3, AD+3) & 0.047 & 0.268 & 0.189 & 0.231 & 1.188 & 0.786 \\
(AD+1, CD-1) & 0.421 & 0.644 & 1.146 & 0.178 & 0.824 & 0.319 \\
(CD-1, CD+1) & 0.188 & 0.485 & 1.167 & 0.028 & 0.157 & 0.441 \\
(CD-2, CD+2) & 0.165 & 0.456 & 0.666 & 0.064 & 0.824 & 0.152 \\
\hline
\end{tabular}




\begin{tabular}{lllllll}
\hline$(\mathrm{CD}-3, \mathrm{CD}+3)$ & 0.073 & 0.297 & 0.200 & 0.083 & 0.154 & 0.145 \\
$(\mathrm{CD}, \mathrm{CD}+4)$ & 0.025 & 0.297 & 0.118 & 0.260 & 1.272 & 0.637 \\
$(\mathrm{CD}+1, \mathrm{CD}+10)$ & 0.454 & 0.268 & 0.825 & 0.137 & 0.517 & 0.478 \\
$(\mathrm{CD}+5, \mathrm{CD}+10)$ & 0.211 & 0.109 & 0.500 & 0.390 & 0.741 & 0.517 \\
$(\mathrm{AD}, \mathrm{CD}+10)$ & 0.550 & 1.585 & 0.842 & 0.168 & 0.517 & 0.329 \\
$(\mathrm{AD}-15, \mathrm{CD}+10)$ & 0.683 & 1.020 & 0.829 & 0.447 & 0.070 & 0.214 \\
$(\mathrm{AD}, \mathrm{CD}+30)$ & 1.080 & $2.149 * *$ & 1.258 & 0.204 & 0.070 & 1.260 \\
$(\mathrm{AD}-15, \mathrm{CD}+60)$ & 2.863 & 0.109 & $1.820^{*}$ & 2.238 & 0 & 0.07 \\
\hline
\end{tabular}

Note. ${ }^{*}, * *$, and $* * *$ denote significance at the 10,5 and $1 \%$ level, respectively.

According to the Panel B of Table 6, the statistic results on the pre-announcement (pre-AD) window show that CAAR is negative and statistically significant, which is also the case for the first AD window (AD-1, AD +1$)$, suggesting that there is an anticipation effect for newly excluded stocks. However, there is no evidence of an announcement effect because CAARs are negative and statistically insignificant across the other AD windows. The results for all the run-up and release-related windows examined are mixed, positive and negative, but all are statistically insignificant, with the exception of the final post-release window $(\mathrm{CD}+5, \mathrm{CD}+10)$, that shows a weak statistical significance for negative CAAR, probably due to a lagged market response on the change date for index exclusion stocks. Finally, the findings from the temporary price and permanent price windows suggest that the limited evidence found that markets penalize firms for being excluded from the index is later reversed.

\subsection{Industry Group Leader Results (H2)}

Table 7 reports on the CAARs in the first 5 trading days after AD and CD for industry group leader stocks. While a general positive trend is evident, there is not a short term announcement effect or change effect.

Table 7. CAARs in smaller event windows for the sample of $\mathrm{H} 2$

\begin{tabular}{lccc}
\hline Period 2009-2013 & \multicolumn{3}{c}{ Industry group leaders } \\
Event window & CAAR (\%) & Sign-test statistic & t-test \\
\hline (AD, $\mathrm{AD})$ & 0.094 & 1.081 & 0.590 \\
$(\mathrm{AD}+1, \mathrm{AD}+1)$ & 0.008 & 0.179 & 0.048 \\
$(\mathrm{AD}+2, \mathrm{AD}+2)$ & 0.311 & 0.935 & 1.914 \\
$(\mathrm{AD}+3, \mathrm{AD}+3)$ & 0.037 & 0.431 & 0.234 \\
$(\mathrm{AD}, \mathrm{AD}+4)$ & 0.335 & 1.187 & 0.743 \\
$(\mathrm{CD}, \mathrm{CD})$ & 0.149 & 0.179 & 1.031 \\
$(\mathrm{CD}+1, \mathrm{CD}+1)$ & 0.088 & 0.431 & 1.018 \\
$(\mathrm{CD}+2, \mathrm{CD}+2)$ & 0.170 & 0.683 & 0.445 \\
$(\mathrm{CD}+3, \mathrm{CD}+3)$ & 0.156 & 0.683 & 1.060 \\
$(\mathrm{CD}+4, \mathrm{CD}+4)$ & 0.127 & 1.585 & 0.847 \\
$(\mathrm{CD}, \mathrm{CD}+4)$ & 0.259 & 0.073 & 0.644 \\
\hline
\end{tabular}

Note. ${ }^{*}, * *$, and $* * *$ denote significance at the 10,5 and $1 \%$ level, respectively.

Figure 2 shows that there is a hint of anticipation effect due to the fact that the CAAR starts increasing from slightly negative values a few days before the announcement. Moreover, unlike with the index inclusion stocks it does not seem to be any loss momentum for the group leader stocks. Finally, while there are some dips along the event period, the abnormal returns show continuous growth, suggesting that the market rewards firms that have been recognized as industry group leader.

Table 8 shows that the CAAR on the pre-AD (AD-10, AD-1) window is positive, but statistically insignificant, suggesting that, contrary to what expected from Figure 2, the market does not anticipate the announcement of industry group leaders. The same conclusion accrues from the results of the various AD windows with lengths ranging from 1, 2 to 3 days before or after the announcement day.

Run-up windows $(A D+1, C D-1),(C D-1, C D+1)$ and $(C D-3, C D+3)$ as well as the post-release windows $(\mathrm{CD}+1, \mathrm{CD}+10)$ and $(\mathrm{CD}+5, \mathrm{CD}+10)$ have positive CAARs combined with significant sign- and/or test-statistics, suggesting that the market reacts to the recognition of industry group leaders after the announcement of their achievement is made. 


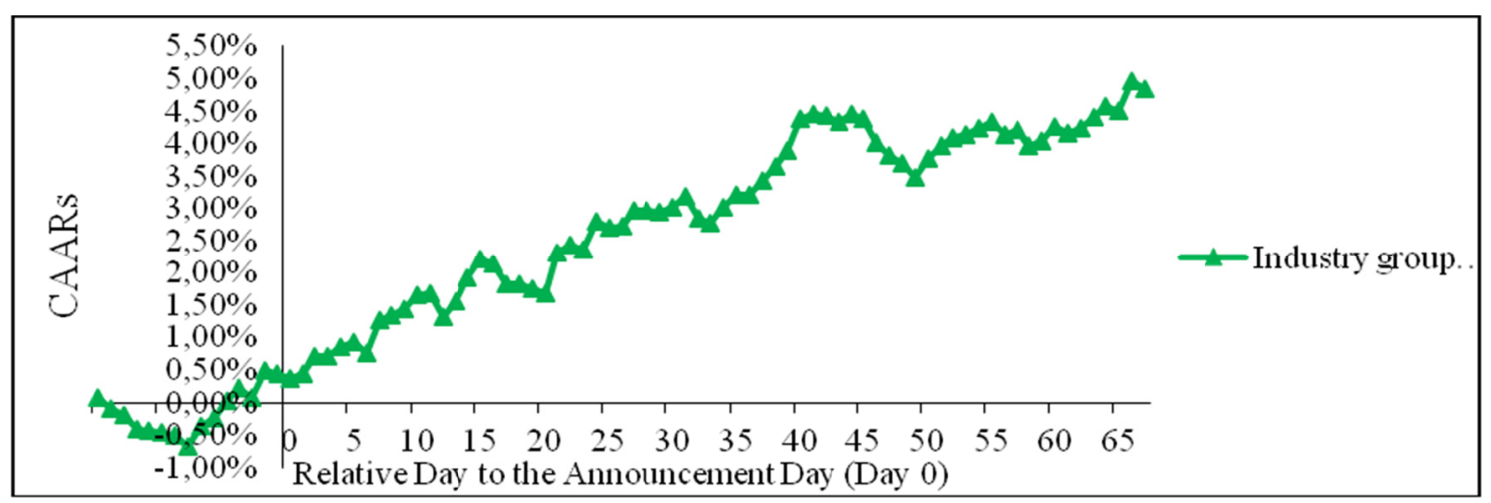

Figure 2. CAARs for the sample of $\mathrm{H} 2$

The results from the first temporary price window $(\mathrm{AD}, \mathrm{CD}+10)$ and the two permanent price windows indicate that there is a positive price effect relating to the event, as for all of them very high and statistically significant CAARs were found. Hence, it emerges that the market does respond positively to firms being recognized for their 'high' CSP.

Table 8. CAARs in smaller event windows for the sample of $\mathrm{H} 2$

\begin{tabular}{|c|c|c|c|}
\hline \multirow{2}{*}{$\begin{array}{l}\text { Period 2009-2013 } \\
\text { Event window }\end{array}$} & \multicolumn{3}{|c|}{ Industry group leaders } \\
\hline & CAAR (\%) & Sign-test statistic & t-test \\
\hline$(\mathrm{AD}-10, \mathrm{AD}-1)$ & 0.196 & 0.431 & 0.377 \\
\hline$(\mathrm{AD}-1, \mathrm{AD}+1)$ & 0.246 & 0.829 & 1.157 \\
\hline$(\mathrm{AD}-2, \mathrm{AD}+2)$ & 0.293 & 0.683 & 0.949 \\
\hline$(\mathrm{AD}-3, \mathrm{AD}+3)$ & 0.484 & 0.935 & 1.270 \\
\hline$(\mathrm{AD}+1, \mathrm{CD}-1)$ & 0.769 & 1.439 & $2.414 * *$ \\
\hline$(\mathrm{CD}-1, \mathrm{CD}+1)$ & 0.350 & 1.439 & $1.934 *$ \\
\hline$(\mathrm{CD}-2, \mathrm{CD}+2)$ & 0.196 & 0.935 & 0.817 \\
\hline$(\mathrm{CD}-3, \mathrm{CD}+3)$ & 0.621 & $2.699 * *$ & $2.128 * *$ \\
\hline$(\mathrm{CD}, \mathrm{CD}+4)$ & 0.259 & 0.073 & 0.644 \\
\hline$(\mathrm{CD}+1, \mathrm{CD}+10)$ & 0.611 & $1.691 *$ & 1.394 \\
\hline$(\mathrm{CD}+5, \mathrm{CD}+10)$ & 0.703 & 1.187 & 1.870 \\
\hline$(\mathrm{AD}, \mathrm{CD}+10)$ & 1.333 & $2.195 * *$ & $2.079 * *$ \\
\hline$(\mathrm{AD}-15, \mathrm{CD}+10)$ & 0.862 & 0.683 & 0.961 \\
\hline$(\mathrm{AD}, \mathrm{CD}+30)$ & 4.790 & $2.447 * *$ & $3.107 * *$ \\
\hline$(\mathrm{AD}-15, \mathrm{CD}+60)$ & 4.35 .5 & $1.691 *$ & $2.086 * *$ \\
\hline
\end{tabular}

Note. ${ }^{*}, * *$, and $* * *$ denote significance at the 10,5 and $1 \%$ level, respectively.

\subsection{Robustness Test}

The estimation window used in this event study is from $t=-250$ to $t=-16$. The first robustness check was conducted on a shorter estimation window of 200 days and the results were essentially the same. For the second check an even shorter estimation window of 150 days was employed. Although, no differences in significance levels were found, it is worth mentioning that, in general, the CAARs for index exclusion stocks became even more negative, while there was little impact on the index inclusion stocks.

\section{Conclusion, Limitations and Recommendations}

This paper aims to investigate whether the market rewards firms being recognized for their high sustainable performance by analyzing the impact of firms' inclusion and exclusion from the Dow Jones Sustainability Index Europe from 2009 to 2013, in terms of abnormal stock returns. Furthermore, it is examined the impact on stock returns for European firms being recognized as industry group leaders by the DJSI Europe over the same period.

The analysis revealed that the event announcement had no significant impact on the stock returns for both firm inclusion in and exclusion from the DJSI Europe. However, there was some evidence that the market anticipated the announcement of firms' exclusion from the index, as these firms witnessed a significant stock return decrease 
10 days prior to the announcement. Moreover, after the effective day of change, stocks included in the index experience an increase in their returns, while those excluded from the index suffer from a decrease in returns. However, these impacts were temporary, especially for index included stocks, given that while these witnessed a significant increase in stock returns up to 30 days after the announcement date, a significant price reversal appears when examining a larger time period (i.e. 60 days).

These research results are consistent with the price pressure hypothesis. There was only limited evidence of an announcement impact on stock prices, and this effect was only observed for stocks exclusion, which rules out the signaling hypothesis, that assumes that there should be price responses for both stocks' index inclusion and exclusion toward the announcement. Furthermore, the analysis revealed that there is no permanent change in the security price for both the stocks included in and excluded from the index. This rejects the downward sloping demand hypothesis and the information cost hypothesis, as they support that any change in stock prices must be permanent. Finally, the fact that there were temporary changes for both groups of stocks is consistent with the price pressure hypothesis, which predicts only a temporary change in price.

The research results for the industry group leader companies are quite different. While a significant short term announcement effect or change effect in not evident, in the long run industry group leaders achieve a rather high, and statistically significant, cumulative average increase of $4.3 \%$ in abnormal stock returns. Hence, it can be concluded that investors reward those firms being recognized to excel in CSP, in terms of a permanent price increase for these securities. This finding can be explained by the resource view of stakeholder theory, which suggests that firms that invest in CSP have superior resources (Alexander \& Bucholz, 1978; Waddock \& Graves, 1997; Clarkson et al., 2006). The resource view proposes that only firms with sufficient resources have the capacity to invest in CSP, and suggests that CSP is positively associated with financial performance, because the firms that invest in CSP have greater underlying resources which produce higher financial performance. As the industry group leaders are more prominently announced than the firms that are added or deleted in the index, this may prompt investors to focus more on the industry leaders because these are the top CSP performers amongst the entire index.

\section{References}

Ahern, K. R. (2009). Sample Selection and Event Study Estimation. Journal of Empirical Finance, 16(3), 466-482. http://dx.doi.org/10.1016/j.jempfin.2009.01.003

Alexander, G. J., \& Buchholz, R. A. (1978). Corporate Social Responsibility and Stock Market Performance. The Academy of Management Journal, 21(3), 479-486. http://dx.doi.org/10.2307/255728

Bauer, R., Koedijk, K., \& Otten, R. (2005). International evidence on ethical mutual fund performance and investment style. Journal of Banking and Finance, 29, 1751-1767. http://dx.doi.org/10.1016/j.jbankfin.2004.06.035

Becchetti, L., Di Giacomo, S., \& Pinnacchio, D. (2008). Corporate social responsibility and corporate performance: Evidence from a panel of US listed companies. Applied Economics, 40, 541-567. http://dx.doi.org/10.1080/00036840500428112

Brammer, S., Brooks, C., \& Pavelin, S. (2006). Corporate Social Performance and Stock Returns: UK Evidence from Disaggregate Measures. Financial Management, 35(3), 97-116. http://dx.doi.org/10.1111/j.1755-053X.2006.tb00149.x

Carroll, A. B., \& Shabana, K. M. (2010). The business case for corporate social responsibility: A review of concepts, research and practice. International Journal of Management Reviews, 12(1), 85-105. http://dx.doi.org/10.1111/j.1468-2370.2009.00275.x

Cheung, A. (2011). Do stock investors value corporate sustainability? Evidence from an event study. Journal of Business Ethics, 99, 145-165. http://dx.doi.org/10.1007/s10551-010-0646-3

Chih, H. L., Chih, H. H., \& Chen, T. Y. (2010). On the Determinants of Corporate Social Responsibility: International Evidence on the Financial Industry. Journal of Business Ethics, 93, 115-135. http://dx.doi.org/10.1007/s10551-009-0186-X

Clarkson, M. B. E. (1995). A Stakeholder Framework for Analyzing and Evaluating Corporate Social Performance. The Academy of Management Review, 20(1), 92-117. Retrieved from http://www.jstor.org/stable/258888

Consolandi, C., Jaiswal-Dale, A., Poggiani, E., \& Vercelli, A. (2009). Global Standards and Ethical Stock Indexes: The Case of the Dow Jones Sustainability Stoxx Index. Journal of Business Ethics, 87, 185-197. 
http://dx.doi.org/10.1007/s10551-008-9793-1

Cormier, D., \& Magnan, M. (2006). The revisited contribution of environmental reporting to investors' valuation of a firm's earnings: An international perspective. Ecological Economics, 62, 613-626. http://dx.doi.org/10.1016/j.ecolecon.2006.07.030

Corrado, C. J., \& Zivney, T. L. (1992). The Specification and Power of the Sign Test in Event Study Hypothesis Test Using Daily Stock Returns. The Journal of Financial and Quantitative Analysis, 27(3), 465-478. http://dx.doi.org/10.2307/2331331

Curran, M. M., \& Moran, D. (2007). Impact of the FTSE4 Good Index on firm price: An event study. Journal of Environmental Management, 82(4), 529-537. http://dx.doi.org/10.1016/j.jenvman.2006.02.010

Denis, D., McConnell, J., Ovtchinnikov, A., \& Yu, Y. (2003). S\&P 500 Index Inclusions and Earnings Expectations. Journal of Finance, 58, 1821-1840. http://dx.doi.org/10.1111/1540-6261.00589

Dhillon, U., \& Johnson, H. (1991). Changes in the Standard and Poor's 500 List. The Journal of Business, 64(1), 75-85. http://dx.doi.org/10.1086/296526

Dow Jones Sustainability Europe Index Guide. (2014). Retrieved from http://www.sustainability indices.com/images/djsidiversifiedguidebook_tcm1071-367705.pdf

Freedman, M., \& Patten, D. (2004). Evidence on the Pernicious Effect of Financial Report Environmental Disclosure. Accounting Forum, 28(1), 27-41. http://dx.doi.org/10.1016/j.accfor.2004.04.006

Freeman, R. E. (1984). Strategic management: A stakeholder approach. Boston: Pitman.

Garcia-Castro, R., Arino, M. A., \& Canela, M. A. (2010). Does social performance really lead to financial performance? Accounting for endogeneity. Journal of Business Ethics, 92, 107-126. http://dx.doi.org/10.1007/s10551-009-0143-8

Harris, L., \& Eitan, G. (1986). Price and Volume Effects Associated with Changes in the S\&P 500 List: New Evidence for the Existence of Price Pressures. The Journal of Finance, 41(4), 815-829. http://dx.doi.org/10.1111/j.1540-6261.1986.tb04550.x

Jain, P. (1987). The Effect on Stock Price from Inclusion in or Exclusion from S\&P 500. Financial Analysts Journal, 43(1), 58-65. http://dx.doi.org/10.2469/faj.v43.n1.58

Jones, S., Frost, G., Loftus, J., \& Van der Laan, S. (2007). An Empirical Examination of the Market Returns and Financial Performance of Entities Engaged in Sustainability Reporting. Australian Accounting Review, 17(41), 78-87. http://dx.doi.org/10.1111/j.1835-2561.2007.tb00456.x

Konar, S., \& Cohen, M. A. (2001). Does the market value environmental performance? The Review of Economics and Statistics, 83(2), 281-289. http://dx.doi.org/10.1162/00346530151143815

KPMG. (2005, 2008, 2011). International survey of corporate responsibility reporting. Amsterdam: KPMG.

Lo, S. F., \& Sheu, H. J. (2007). Is Corporate Sustainability a Value-Increasing Strategy for Business? Corporate Governance, 15(2), 345-358. http://dx.doi.org/10.1111/j.1467-8683.2007.00565.x

Lopez, V. M., Garcia, A., \& Rodriguez, L. (2007). Sustainable Development and Corporate Performance: A Study Based on the Dow Jones Sustainability Index. Journal of Business Ethics, 75, 285-300. http://dx.doi.org/10.1007/s10551-006-9253-8

Lorraine, N. H. J., Collison, D. J., \& Power, D. M. (2004). An Analysis of the Stock Market Impact of Environmental Performance Information. Accounting Forum, 28, 7-26. http://dx.doi.org/10.1016/j.accfor.2004.04.002

Lourenço, I. C., Branco, M. C., Curto, J. D., \& Eugenio, T. (2012). How does the market value corporate sustainability performance? Journal of Business Ethics, 108, 417-428. http://dx.doi.org/10.1007/s10551-011-1102-8

Lynch, A., \& Mendenhall, R. (1997). New Evidence on Stock Price Effects Associated with Changes in the S\&P 500. Journal of Business, 70, 351-384. http://dx.doi.org/10.1086/209722

MacKinlay, A. C. (1997). Event Studies in Economics and Finance. Journal of Economic Literature, 35, 13-39.

Margolis, J. D., \& Walsh, J. P. (2001). People and profits? The search for a link between a company's social and financial performance. Mahwah, NJ: Lawrence Erlbaum Associates.

McWilliams, A., Siegel, D., \& Wright, P. M. (2006). Guest editors' introduction: Corporate social responsibility: 
Strategic implications. Journal of Management Studies, $43(1), \quad$ 1-18. http://dx.doi.org/10.1111/j.1467-6486.2006.00580.x

Merton, R. C. (1987). A Simple Model of Capital Market Equilibrium with Incomplete Information. The Journal of Finance, 42(3), 483-510. http://dx.doi.org/10.1111/j.1540-6261.1987.tb04565.x

Obernorfer, U., Schmidt, P., Wagner, M., \& Ziegler, A. (2013). Does the stock market value the inclusion in a sustainability index? An event study analysis for German firms. Journal of Environmental Economics and Management, 66, 497-509. http://dx.doi.org/10.1016/j.jeem.2013.04.005

Orlitzky, M., Schmidt, F. L., \& Rynes, S. L. (2003). Corporate social and financial performance: A meta-analysis. Organization Studies, 24(3), 403-441. http://dx.doi.org/10.1177/0170840603024003910

Roberts, P. W., \& Dowling, G. R. (2002). Corporate reputation and sustained superior financial performance. Strategic Management Journal, 23, 1077-1093. http://dx.doi.org/10.1002/smj.274

Roberts, R. W. (1992). Determinants of corporate social responsibility disclosure: An application of stakeholder theory. Accounting, Organizations and Society, 17(6), 595-612. http://dx.doi.org/10.1016/0361-3682(92)90015-K

Ruf, B. M., Muralidhar, K., Brown, R., Janney, J. J., \& Paul, K. (2001). An Empirical Investigation of the Relationship Between Change in Corporate Social Performance and Financial Performance: A Stakeholder Theory Perspective. Journal of Business Ethics, 32, 143-156. http://dx.doi.org/10.1023/A:1010786912118

Shleifer, A. (1986). Do Demand Curves for Stocks Slope Down? Journal of Finance, 41(3), 579-590. http://dx.doi.org/10.1111/j.1540-6261.1986.tb04518.x

Solomon, J., \& Solomon, A. (2006). Private social, ethical and environmental disclosure. Accounting, Auditing \& Accountability Journal, 19(4), 564-591. http://dx.doi.org/10.1108/09513570610679137

Solomon, J., Solomon, A., Norton, S., \& Joseph, N. (2011). Private climate change reporting: An emerging discourse of risk an opportunity? Accounting, Auditing \& Accountability Journal, 24(8), 1119-1148. http://dx.doi.org/10.1108/09513571111184788

$\begin{array}{llllll}\text { STOXX } & \text { Europe } & 600 & \text { Index. } & \text { (2014). } & \text { Retrieved }\end{array}$ http://www.stoxx.com/indices/index_information.html?symbol=SXXP

Ullman, A. E. (1985). Data in search of a theory: A critical examination of the relations among social performance, social disclosure and economic performance of U.S. firms. Academy of Management Review, $10(3), 540-557$.

Waddock, S. A., \& Graves, S. B. (1997). The corporate social performance-financial performance link. Strategic $\begin{array}{llll}\text { Management } \quad \text { Journal, } & \text { 303-319. }\end{array}$ http://dx.doi.org/10.1002/(SICI)1097-0266(199704)18:4<303::AID-SMJ869>3.0.CO;2-G

Wood, D. J. (1991). Corporate social performance revisited. Academy of Management Review, 16, 691-718.

Wood, D. J. (2010). Measuring corporate social performance: A review. International Journal of Management Reviews, 12(1), 50-84. http://dx.doi.org/10.1111/j.1468-2370.2009.00274.x

Ziegler, A. (2012). Is it beneficial to be included in a sustainability stock index? A panel data study for European firms. Environmental Resource Economics, 52, 301-325. http://dx.doi.org/10.1007/s10640-011-9529-z

Ziegler, A., \& Schröder, M. (2010). What determines the inclusion in a sustainability stock index? A panel data analysis for European firms. Ecological Economics, 69, 848-856. http://dx.doi.org/10.1016/j.ecolecon.2009.10.009

\section{Copyrights}

Copyright for this article is retained by the author(s), with first publication rights granted to the journal.

This is an open-access article distributed under the terms and conditions of the Creative Commons Attribution license (http://creativecommons.org/licenses/by/3.0/). 